\title{
A DYNAMIC VIEW OF TRIBAL JURISDICTION TO TAX NON-INDIANS*
}

\author{
Carole E. Goldberg $\dagger$
}

Domestic dependent nations are permitted an existence in the United States so long as they are weak.'

Just as Indian land was the object of white settlers in the nineteenth century, so Indian minerals are the object of white-dominated urban centers hungry for additional sources of energy in the twentieth century. If Indian tribes are to benefit from contemporary circumstances, however, it will probably be necessary to alter the political and economic system associated with the allocation of these resources. In order to achieve this goal, tribes may choose, among other means, to bargain for a percentage of the profits derived from access to their resources. Greater benefits, however, may result from the exercise by Indian tribes of the power to tax non-Indian developments on reservation lands. ${ }^{2}$

The imposition of taxes on non-Indians poses a set of legal issues that cannot be considered in a political and institutional vacuum. Despite the long-standing legal characterization of Indian tribes as "semi-sovereign"

\footnotetext{
* This article was supported by the National Science Foundation, RANN Division, Research Grant Number NSF 61-294-22 to the Lake Powell Research Project.

$\dagger$ Professor of Law, University of California, Los Angeles School of Law.

1. M. Shepardson, Navajo Ways in Government 113 (American Anthropological Ass'n Memoir 96, 1963).

2. Traditionally, Indian tribes have settled for fixed royalties in exchange for mineral leases. Taxation can be a more lucrative future alternative to royalties than joint venture investment because it can supplement long term royalty agreements that have failed to keep pace with current market prices. For example, coal is now worth three to four times as much as when leases for extraction of much of Navajo coal were signed, "but the Navajos still receive $15 c$ to $25 \%$ a ton ... whereas Montana receives a royalty of $40 x$ or more for coal taken from state lands and the Crow Indians receive a sliding scale with a $40 t$-a-ton minimum." Reno, High, Dry and Penniless, 220 The Nation 359,361 (1975). Furthermore, the gains possible from taxation of massive new industrial developments are staggering. The New Mexico Revenue Commission has estimated that contemplated coal gasification plants on the eastern end of the Navajo Reservation would bring in the following sums at current prices and tax rates: $\$ 20$ million per plant from a tax on contractors for the value of the completed project; $\$ 51$ million from a sales tax on coal sold to power the gasification plants (assuming seven such plants operating for twenty-five years); over $\$ 3$ million per year from severance and natural resource excise taxes; $\$ 12.5$ million from a property tax on production; plus additional sums from income taxation of non-Navajos. Gasification Plants Face Sales Tax, Farmington (N.M.) Daily Times, Feb. 17, 1975, at 8, cols. 1-5. If tribal taxation could preempt state taxation, all these revenues could go far towards meeting the goals of the Navajo Tribe's recently adopted Ten-Year Plan. Navajo Nation, The Navajo Ten-YEar Plan (1972). According to the plan, $\$ 3.8$ billion is needed over the next ten years if Navajos are to enjoy a standard of living at the national average. See also Office of Program Development, Navajo Tribe, The Navajo Nation: Overall Economic Development Program (1974).
} 
entities, ${ }^{3}$ tribes have been reluctant to assert as broad a range of jurisdictional powers as those exercised by the states. ${ }^{4}$ They have recognized that a legal victory may lead to a political defeat, that gains in one area may result in the unwelcome imposition of new restraints or requirements in another. Therefore, to understand the implications of the legal doctrine of Indian taxing power it is essential to take a dynamic view of the relation between legal constructs on the one hand, and on the other, the political-institutional context of their development. Using the large, energy-rich Navajo Nation as a case study, this article will explore the legal, political, and institutional limitations on the exercise by Indian tribes of the power to tax non-Indians.

\section{The Origin and Functions of Navajo Tribal Government}

The ability to extend the range of Indian tribal powers depends, in large part, on the political structure that has developed as the result of various federal, state, and tribal relationships. The current division of Navajo tribal government into executive, legislative, and judicial branches ${ }^{5}$ was set by and intended to further the aims of the federal government. Prior to contact with whites the Navajo possessed no centralized government or overall leader, disputes being resolved with the aid of non-hereditary clan leaders and respected mediators. ${ }^{6}$ Following the military defeat of the Navajo and the imposition of the resettlement provisions of the Treaty of 1868, the tribe was

3. Worcester v. Georgia, 31 U.S. (6 Pet.) 515 (1832).

4. To the extent that modern Indian governments have punished, taxed, zoned, or otherwise regulated activities on their reservations, they have generally done so only if those activities were undertaken by Indians of their own tribe or another. See, e.g., TASK Force on INDIAN-STATE Government Relations, Staff Report on Taxation, State of South Dakota D1-10 (1973), describing tax collection agreements between the state and the Pine Ridge Tribe, whereby the state agreed to collect and return a four per cent sales tax which the tribe had levied on Indian purchases on the reservation. The state collects a four per cent tax on non-Indian purchases on the reservation.

5. The legislative branch consists of a Tribal Council whose members are elected by Navajos from designated districts within the reservation. Secretary of the Interior, Rules for the Tribal Council, in R. Young, Navajo Yearbook 407 (1961); 2 N.T.C. (Navajo Tribal Code) \& 101 (1972). There are standing committees, 2 N.T.C. $\$ \S 361-802$ (1972), and an Advisory Council that exercises the Council's powers when it is not in session. 2 N.T.C. $\$ \$ 341-49$ (1972). The executive branch consists of a tribal Chairman, Vice-Chairman, and numerous administrative departments, the Chairman and Vice-Chairman being elected by vote of all enrolled members of the tribe. Rules for the Tribal Council, in R. Young, supra at 408; 2 N.T.C. $\$$ 4, 281-89 (1972). The judicial branch has several trial courts and an appellate court in which cases are heard de novo. Judges are appointed by the Chairman with the approval of the Council. 7 N.T.C. $\$ \$ 101$, 131-73 (1969). For a description of the Navajo judiciary, see Davis, Court Reform in the Navajo Nation, 43 J. Am. Jud. Soc'y 53 (1959); Judicial Branch, Navajo Nation, Annual Report (1973). Navajo institutions are among the most complex of Indian tribes. Compare, for example, the tribal governments described in detail in american Indian Lawyer Training Program, Indian Tribes as Governments (1975).

6. A. Williams, Navajo Political Process 6-7, 24 (1970); M. Shepardson, supra note 1, at 3 
subject to varying federal policies. In the 1920 s the federal government sponsored the creation of an elected tribal government. The purpose of this program was to establish "indirect rule" of the tribe, to legitimize federal decisions concerning the allocation of reservation resources, and to further the assimilation of the Navajo into the dominant society. ${ }^{7}$ The current Navajo Tribal Council still functions under by-laws issued by the Secretary of the Interior in $1938 .^{8}$ There is no tribal constitution authorizing the Council, since the Navajos declined to accept the provisions of the Indian Reorganization Act of 1934 which would have required such a constitution, ${ }^{9}$ the Secretary of the Interior refused to approve an independently drafted Navajo constitution, ${ }^{10}$ and the constitution authorized by the Navajo-Hopi Rehabilitation Act $^{11}$ was never promulgated. The Secretary of the Interior attempts to exercise considerable control over the Council as it is presently constituted, approving or disapproving resolutions and budget items, and even calling for the Council to convene. ${ }^{12}$ It is debatable whether all such powers are authorized by law. ${ }^{13}$

Tribal courts, known as Courts of Indian Offenses, also were originally established by the Secretary of the Interior to hear civil and criminal cases against reservation Indians. The Indian judges for these courts were appointed by the Commissioner of Indian Affairs and paid for with federal funds until 1950, when the Tribal Council resolved that they be elected by the Navajo people. ${ }^{14}$ Finally, in 1959 the Council provided for abolition of the Navajo Courts of Indian Offenses and establishment of the current Navajo judicial system which is an instrumentality of the tribe free from control of the Department of the Interior. ${ }^{15}$

While these contemporary governing institutions of the Navajo Tribe are a federal imposition on traditional Navajo forms of government, they are not fully equivalent to their federal, state, and local counterparts. The Navajo Tribe has few lawyers involved in any branch of government, and its legislature and court system have modest professional staffs. ${ }^{16}$ Statutory law is

7. A. WILliAms, supra note 6 , at 18-26.

8. See Rules for the Tribal Council, in R. Young, supra note 5.

9. R. Younc, supra note 5, at 377; see 25 U.S.C. $\$ 476$ (1970).

10. R. Young, supra note 5, at 379-82.

11. 25 U.S.C. $\$ 636(1970)$.

12. A. Williams, supra note 6 , at 26.

13. See text accompanying notes $45-52$ infra.

14. See Davis, supra note 5.

15. Navajo Tribal Council, Resolution No. C0-69-58, October 16, 1958 (codified in scattered sections of 7,8 N.T.C.).

16. The Tribal Council is assisted by personnel of the Navajo Tribal Legal Office, consisting of two or three state-licensed lawyers. 2 N.T.C. $\$ \$ 951-53,953(10)$ (1972). Although there is no express provision in the Navajo Tribal Code for law clerks for Navajo judges, the judges may by rule of court provide for the creation of such positions. 7 N.T.C. $\$ 254$ (1969). Currently there 
codified in desultory and haphazard fashion. While the tribe is expanding its administrative bureaucracy, it lacks a full complement of specialists possessing the expertise necessary to cope with the growing number of complex decisions related to environmental degradation, cultural change, resource utilization, and planned development. ${ }^{17}$ Bureaucracy exists more on flow charts than in organizational behavior.

Tribal taxation of non-Indians disturbs this federally created political structure in several respects. First, and most obviously, it involves the Indians in assertions of power over non-traditional, non-Indian activity. Second, it can provide the resources necessary to fund a thoroughly professional tribal bureaucracy, capable of maximizing tribal advantages from outsiders' development. Third, it can enable the tribe to become self-sufficient and selfsustaining, reducing the arguments in favor of making the reservation subject to state jurisdiction and terminating trust status. With taxing power over non-Indians, the tribe acquires the potential for equivalence with state governments. Accordingly, it is important to appreciate the new conception of tribal government inherent in the exercise of tribal taxing power over nonIndians, and the political and institutional alterations that may follow from that conception. The possibility of such alterations may lead the courts to redefine the sources of and limitations on tribal taxing power, and Congress to exercise its prerogative to redistribute power over reservation activities. This dynamic is central to the actual development of the legal doctrine of Indian taxing power.

II

Sources of Navajo Taxing Power

Early decisions of the United States Supreme Court proclaimed that Indian tribes possessed all sovereign powers over domestic matters within their territorial boundaries unless the United States decreed to the contrary. ${ }^{18}$ This sovereign power has even been declared free of restrictions emanating from the Bill of Rights. ${ }^{19}$ Since taxing power over all activities conducted on a sovereign's territory is an ordinary incident of sovereignty, under Supreme Court precedent the Navajo Tribe ought to possess this power unless Congress has withdrawn it. ${ }^{20}$ In fact, Congress has not attempted to do so. The

are law school graduates working for the court of appeals. Professionals who can provide probation and parole services are sorely needed. AN NUAL REPORT, supra note 5, at 17.

17. See Cortner, Development, Environment, Indians, and the Southwest Power Controversy, 4 Alternatives 14, 19 (1974).

18. Worcester v. Georgia, 31 U.S. (6 Pet.) 515 (1832); Ex Parte Crow Dog, 109 U.S. 556 (1883).

19. E.g., Native Am. Church v. Navajo Tribal Council, 272 F.2d 131 (10th Cir. 1959); Barta v. Oglala Sioux Tribe, 259 F.2d 553 (8th Cir. 1958).

20. Iron Crow v. Oglala Sioux Tribe, 231 F.2d 89, 99 (8th Cir. 1956). 
1868 Treaty with the Navajos confirms their power to banish undesirable non-Indians from the reservation. ${ }^{21}$ And the Indian Reorganization Act of 1934, although not accepted by the Navajos, manifests Congress's intent that tribal governments possess taxing powers. ${ }^{22}$ The Solicitor of the Department of the Interior, however, has not been willing to extend the broad judicial pronouncements about sovereignty to the ultimate conclusion of recognizing tribal power to impose criminal sanctions on non-Indians for offenses committed on the reservation. ${ }^{23}$ Nevertheless, this limited view of tribal sovereignty need not jeopardize tribal taxing power over non-Indians. ${ }^{24}$

In fact the historic definition of Indian sovereign powers is itself a function of the federal government's conception of what tribal governments would want and ought to regulate. As Indian-white contacts expanded, the scope of tribal sovereignty contracted, and the justification for the retention of certain powers was based largely on a recognition of Indian cultural distinctiveness, their geographic isolation, and the perils of precipitous assimilation. ${ }^{25}$ If tribes

21. Treaty With the Navajo Indians, art. II, 15 Stat. 667, 668 (1869); see Dodge v. Nakai, 298 F. Supp. 26 (D. Ariz. 1969).

22. 25 U.S.C. $\$ 476$ (1970); see Barta v. Oglala Sioux Tribe, 259 F.2d 553

23. 77 Interior Dec. $113(1970)$. The use of authority in this opinion is thoroughly criticized in Baldassin \& McDermott, Jurisdiction Over Non-Indians: An Opinion of the "Opinion," 1 Ам. Indian L. REv. 13 (1973). The Solicitor's position, based on a few early lower federal court decisions, has been that Indian tribes are limited to the sanction of banishing non-Indians from the reservation. The implication is that Indian tribes have such distinctive values that it would not be proper to subject a non-Indian to their ordinary modes of punishments, notwithstanding this is ordinarily the risk any alien takes upon entering a foreign country. However, the analogy between whites working on an Indian reservation and Americans working abroad, although appealing, is not fully warranted. Americans do not expect to be able to share the values of local decision-makers when they are abroad. A white on a reservation, however, may have different expectations because he or she is still in his or her own home country.

Despite the broad judicial pronouncements about sovereignty, the Solicitor's opinion implies that Indian tribes are more like private clubs or businesses, capable of imposing sanctions only on those who acquiesce. Contrary to this theory, however, the code adopted by the Department of Interior for Courts of Indian Offenses authorizes criminal jurisdiction over Indians who are not members of the tribe in whose court they are tried. 25 C.F.R. $\$ 11.2(1975)$. At the same time, it excludes even non-Indians who have consented to jurisdiction, although civil jurisdiction is allowed over non-Indians in such cases. 25 C.F.R. $\$ 11.22$ (1975). This characterization of Indian tribes was rejected by the Supreme Court quite recently in United States v. Mazurie, 419 U.S. 544 (1975). Recently several tribes have attempted to acquire criminal jurisdiction over non-Indians by posting notices at the boundaries of the reservation that entry will constitute consent to criminal jurisdiction. See discussion in Vollmann, Criminal Jurisdiction in Indian Country: Tribal Sovereignty and Defendants' Rights in Conflict, 22 U. KAN. L. REv. 387, 394 (1974); 4 NaT'L American Indian Court Judges Ass'n, Justice and the American Indian, Examination of the Basis of Tribal Law and Order Authority 50-56 (1974).

24. The tribe could simply banish any non-Indian who had failed to pay his taxes (lease provisions to the contrary notwithstanding). Indeed, court decisions of the 1950 s confirm this point. Barta v. Oglala Sioux Tribe, 259 F.2d 553; Iron Crow v. Oglala Sioux Tribe, 231 F.2d 89. See also 55 Interior Dec. 14, 45 (1934), in which the Associate Solicitor affirmed the power of the tribe to tax nonmembers who accept privileges of trade and residence. This power was written into the Oglala Sioux Constitution and approved by the Secretary of the Interior. M. Price, Law and The American Indian 717 (1973).

25. Ex Parte Crow Dog, 109 U.S. 556 (1883). 
now attempt to expand their powers to include taxation of non-Indians, the courts may alter their own construction of tribal sovereignty, limiting its scope to enrolled members of the tribe or its implementation to conformity with the Federal Constitution.

Recent decisions by the Department of the Interior and the United States Supreme Court indicate that a redefinition of tribal sovereignty to limit it to Indians in general, or to tribal members in particular, is unlikely. The solicitor has withdrawn his official opinion denying the existence of tribal criminal jurisdiction over non-Indians, ${ }^{26}$ and has failed to disapprove several tribal ordinances imposing criminal jurisdiction over non-Indians on a theory of implied consent. $^{27}$ Furthermore, the Bureau of Indian Affairs's (BIA) policy of contracting with Indian tribes to provide services formerly administered by BIA personnel suggests that strengthening of administrative apparatus on reservations is an important goal. ${ }^{28}$

Most important, in January 1975, the Supreme Court delivered its opinion in United States $\%$. Mazurie, ${ }^{\mathbf{2 9}}$ which reaffirmed the existence of wide tribal authority over non-Indians. The case did not deal with that issue squarely, since the question was whether the federal government could delegate law-making power over non-Indians to the tribes, not whether the tribes themselves could make these laws. Nevertheless, the Supreme Court asserted that the delegation of authority was easier to sustain because the delegate tribe possessed "a certain degree of independent authority over matters that affect the internal and social relations of tribal life," ${ }^{30}$ in this case the distribution and use of intoxicants on the reservation. The Court seemed anxious to avoid a direct statement that tribes could impose such regulations absent federal delegation, but it is difficult to develop a credible theory that would support the federal delegation but not the independent authority.

Of course, the Supreme Court still could define narrowly the class of activities by non-Indians on the reservation that affect the tribe's internal and social relations. For example, confusion and discussion abound in case law and commentary over whether a crime committed by one non-Indian against another non-Indian ought to be classified as such. ${ }^{31}$ Conceivably taxation of

26. Memorandum from Kent Frizell, Solicitor, Dep't of the Interior to Regional and Field Solicitors, Bureau of Indian Affairs, Jan. 25, 1974, in 1 INDIAN L. ReP. no. 2, at 51 (1974).

27. Vollmann, supra note 23 , at 394.

28. T. Taylor, The States and Their Indin Citizens 142-43, 160-67 (1972). This practice was approved of and facilitated by Congress in the Indian Self-Determination and Education Assistance Act of 1974, Pub. L. No. 93-638, §§ 102-10, 88 Stat. 2203.

29. 419 U.S. 544 .

30. 419 U.S. at 557.

31. For a criticism of the case law holding crimes by non-Indians against non-Indians to be outside federal or tribal jurisdiction see Canby, Civil Jurisdiction and the Indian Reseriation, 1973 UTAH L. REv. 206, 208-10; Taylor, Development of Tripartite Jurisdiction in Indian Country, 2 Solicitor's REv. 1, 70-71 (1973); Vollmann, supra note 23, at 395. Recent lower court authority 
non-Indians solely for the purposes of raising revenue might be viewed as a matter unrelated to regulation of internal tribal affairs, even though revenues might be used to redistribute income or to finance needed social services or cultural events. The trend does not seem to be in that direction, however. Rather, it seems to favor reaffirmation of Indian tribes as "unique aggregations possessing attributes of sovereignty over both their members and their territory." 32

Ironically, it is delay by Indian tribes in asserting these powers that ultimately may jeopardize their claim to sovereignty, especially to sovereignty that preempts the states. Most Indian tribes, including the Navajos, have not often attempted to assert and thereby test their sovereign powers with respect to non-Indians. For example, the general provisions for civil and criminal jurisdiction in Navajo tribal courts specify that the defendant must be an Indian. ${ }^{33}$ A resolution to expand this jurisdiction to non-Indian defendants has been introduced in the Tribal Council, but has not even come to a vote. ${ }^{34}$ Quite recently, however, in response to supportive precedent in the courts ${ }^{35}$ and a supportive opinion by the Solicitor of the Department of Interior, ${ }^{36}$ the tribe has asserted jurisdiction over non-Indians who violate tribal laws regulating hunting and fishing. ${ }^{37}$ Similar resolutions, confined to a narrow range of non-Indian activities, have also passed the Council in recent years, ${ }^{38}$ though

suggests that the commentators are having some impact. See Oliphant v. Schlie, Civil No. $511-73 C 2$ (W.D. Wash., filed Apr. 5, 1974) (appeal pending) (upholding tribal jurisdiction over non-Indian charged with resisting arrest by tribal police officer and assaulting the officer); Ortiz-Barraza v. United States, 512 F.2d 1176 (9th Cir. 1975) (upholding the power of tribal police to stop and search non-Indians suspected of violating state or federal law, for purposes of excluding them under applicable tribal law).

32. United States v. Mazurie, 419 U.S. at 557 (emphasis added)

33. 7 N.T.C. $\S 133(\mathrm{a})$, (b) (1969).

34. Navajo Tribal Council, Proposed Resolution, amending Navajo Tribal Council, Resolution No. CJA 5-59, Jan. 9, 1959 (codified in 7 N.T.C.) (To Include Civil and Criminal Jurisdiction Over Non-Indians) (on file with the author). From the tribe's point of view, it was probably too large an initial step into the realm of jurisdiction over non-Indians. It might have produced a test case involving very little tribal interest. An attempt by the Tribal Council to institute a system of hunting and fishing licenses applicable to non-Indians and enforced by tribal courts was thwarted in the late 1960s, when counsel for the tribe contended with misplaced conviction that the tribe possessed no enforcement power. Navajo Tribal Council, Minutes of Meeting 129-40, February 3, 1969. The Resolution as eventually adopted required that non-Indians found in violation of tribal hunting and fishing laws be delivered to federal authorities. 23 N.T.C. $\$ 109$ (1969).

35. E.g., Quechan Tribe of Indians v. Rowe, 350 F. Supp. 106 (S.D. Cal. 1972); see Comment, Indian Regulation of Non-Indian Hunting and Fishing, 1974 WIS. L. Rev. 499. See also Oliphant v. Schlie, Civil No. 51 1-73C2 (W.D. Wash., filed Apr. 5, 1974).

36. See Memorandum, supra note 26.

37. Navajo Tribal Council, Resolution Nos. CAU-46-73, CJN-38-75, June 18, 1975. Significantly, the tribe also has authorized the training and hiring of special tribal law enforcement officers who will be concerned only with arresting people pursuant to these laws. Navajo Tribal Council, Resolution No. CJN-38-75, June 18, 1975 (Exhibit "D": Plan of Operation for the Establishment of a "Wildlife Enforcement Section" Within the Fish and Wildlife Department).

38. One resolution that grants tribal jurisdiction over forcible entry and detainer actions against any "person," has been upheld by the Navajo Court of Appeals as applied to a nonIndian corporation. Navajo Tribe v. Orlando Helicopter Airways, Inc., Civil No. 1-12 (Navajo Ct. 
not necessarily as part of a deliberate plan gradually to extend jurisdiction over non-Indians. ${ }^{39}$ More directly, in January 1974, the Tribal Council authorized the establishment of a Navajo Tax Commission that would report back to the Council on the prospects of taxing non-Indians. ${ }^{40}$ Indicative of the tribe's restraint on this issue is the fact that the Commission was not appointed until April 1976. Meanwhile, the State of New Mexico has moved closer to taxing the same non-Indian assets and income the tribe may want to tap. $^{41}$

Three factors account for the tribe's reluctance to pursue the substantial revenues to be gained from taxing non-Indians. First, many Council members have feared that new taxes will have to be imposed on Navajos as well as non-Navajos. ${ }^{42}$ Second, the Council has sensed that the costs of designing and enforcing a tax structure will, at least initially, be too great a burden. ${ }^{43}$ And finally, there has been concern that the structure of the tribe will be adversely affected when, as part of expanding its jurisdiction, the tribe may have to provide services to non-Indians, share special rights (e.g., voting, jury duty) with non-Navajos, and create a more Anglicized political structure. It is reasonable for tribal leaders to expect that after courts have reaffirmed, and the tribe has asserted, new and far-reaching sovereign powers, courts, the Department of Interior, and Congress will initiate fresh discussions of the limits on how tribal authority may be exercised.

III

\section{Sources of Possible Restrictions on Tribal Taxing Power}

\section{A. Federal Power to Approve or Disapprove Tribal Council Decisions}

The courts have been willing to recognize broad tribal power over Indians in part because they recognize as a restraining factor the requirement that the

\footnotetext{
App., filed Jan. 12, 1972); see Note, Indian Tribal Courts-Jurisdiction-Navajo Court Jurisdiction Over Non-Indian Defendants, 18 ST. Louis U.L.J. 461 (1974). Another authorizes the recently established Navajo Environmental Protection Commission to seek imposition of fines on non-Indian as well as Indian polluters. Navajo Tribal Council, Resolution No. CAU 72-72, Aug. 10, 1972.

39. Navajo Tribal Council, Minutes of Meeting, Nov. 21, 1969, concerning Navajo Tribal Council, Resolution No. CN-100-69, November 21, 1969 and Navajo Tribal Council, Resolution No. CAU-72-72, August 10, 1972.

40. Navajo Tribal Council, Resolution No. CJA-6-74, January 16, 1974. The tribe had before it a study prepared by Professor Gerald Boyle of the Department of Economics, University of New Mexico, concerning appropriate sources of tax revenue on the reservation. G. Boyle, Revenue Alternatives for the Navajo Nation (University of New Mexico Working Papers in Economics 1973).

41. See Farmington (N.M.) Daily Times, supra note 2.

42. Navajo Tribal Council, Minutes of Meeting 41-64, January 16, 1974. This fear was fed by a consultant's report on Navajo taxation which recommended imposition of a payroll tax. See G. BOY LE, supra note 40 , at 13-15.

43. The tribe does not even have an adequate means of auditing and enforcing royalty and lease obligations of lessees. G. BoYLE, supra note 40, at 17-19.
} 
Secretary of the Interior must approve all tribal ordinances. ${ }^{44}$ Because of its unusual origin, the Navajo Tribal Council enjoys more independence from the Secretary of the Interior than do most tribal governments. Had the Navajos adopted a constitution under the Indian Reorganization Act of 1934, it probably would have followed the BIA's model provisions, including a requirement that all tribal resolutions be approved by the Secretary before becoming effective. ${ }^{45}$ Since the Navajos refused not only that invitation to establish a constitution, but also the more personal one embodied in the 1954 Navajo-Hopi Rehabilitation Act, ${ }^{46}$ the Council continues to act under some sketchy rules promulgated by the Secretary of the Interior in 1938-rules intended to be only temporary. Thus, although the Navajo Tribal Council operates as if the Navajo people had formally vested it with their sovereign power, it is technically the creation of secretarial rules. These rules do not, however, define or limit what the Council may do. Neither do they require secretarial approval of all tribal resolutions. They simply provide for elections and terms of office for members of the Tribal Council, the Chairman, and the Vice-Chairman. ${ }^{47}$ While Congress could limit the Council's powers and require secretarial approval, it has not done so. ${ }^{48}$

The Navajo Tribal Code nevertheless contains statements that tribal law and order regulations must be approved by the Secretary before becoming effective. ${ }^{49}$ While tax laws do not fall into this category, it has been the general practice for many years for the tribe to submit resolutions to the Secretary for his signature. A signal that this practice may be terminated is the holding of the Court of Appeals for the Navajo Tribe in the case of Narajo Tribe of Indians \% Holyan. The court concluded that even where the tribe has expressly provided for secretarial approval, the submission is unnecessary and the Secretary's action "a meaningless formality." Congress and the Secretary have not ordered the submission, and the tribe cannot voluntarily relinquish its sovereignty. In spite of this decision, submission of resolutions to the Secretary continues.

44. Thus, the Court in United States v. Mazurie, 419 U.S. 544, 558 n.12 (1975) noted with favor that the Secretary must approve any tribal ordinance limiting sale of liquor on the reservation before violation of the ordinance becomes a federal offense. See text accompanying notes 29-30 supra.

45. See M. Price, supra note 24 , at $717-19$.

46. 25 U.S.C. $\$ 636(1970)$.

47. See Rules for the Tribal Council, in R. Youvg, supra note 5 .

48. It is debatable whether, in the absence of specific congressional direction, the secretary could require such approval under the general delegation of authority in 25 U.S.C. $\$ 2$ (1970). Although there is little judicial guidance to its limits, this section has been interpreted narrowly in recent years. E.g., Organized Village of Kake v. Egan, 369 U.S. 60, 63 (1962); Norvell v. Sangre de Cristo Dev. Co., 372 F. Supp. 348, 354-55 (D.N.M. 1974), revid on other grounds, 519 F.2d 370 (10th Cir. 1975).

49.7 N.T.C. $\$ 1(\mathrm{e})(1969) ; 17$ N.T.C. $\$ 1$ (1969).

50. Navajo Tribe of Indians v. Hoylan, Civil No. 8-22 (Navajo Ct. App., filed Aug. 22, 1 $\overline{9} 73$ ). 
Although there seems to be no direct secretarial barrier to Navajo imposition of taxes on non-Indian development, the absence of such a barrier will not necessarily enhance the sovereign powers of the tribe. The existence of a potential federal check, as in the Mazurie case ${ }^{51}$ and as is true for most Indian tribes, may make courts more relaxed about recognizing tribal power to tax non-Indians, or more inclined to find a taxing ordinance within the permissible limits of the Indian Civil Rights Act. On the other hand, the Secretary can exercise some indirect control over Navajo legislation. Under section seven of the Navajo-Hopi Rehabilitation Act, tribal power to appropriate "funds" is subject to secretarial approval. ${ }^{52}$ Whether expenditures of tax revenues collected by the tribe are subject to this limitation is uncertain. The reference may only be to rentals, royalties, and federal appropriations. But assuming any tribal funds may be spent only after secretarial approval, some indirect federal supervision of tribal policies does exist, although perhaps not enough to convince courts that tribal jurisdiction over non-Indians will reflect dominant values and political preferences.

\section{B. The Indian Civil Rights Act}

Another well-spring of federal power to regulate Indian tribes, that may shape the use of tribal taxing power, is the Indian Civil Rights Act. ${ }^{53}$ Enacted in 1968 , this statute was designed to restrain the actions of tribal councils with respect to Indians and non-Indians ${ }^{54}$ by requiring conformity with the dominant values expressed in the Bill of Rights. ${ }^{55}$ The Act does not render all ten constitutional amendments applicable to the tribes; nor is it clear that the language in the Act making certain amendments applicable to tribal governments means the same in a tribal context as it does elsewhere. ${ }^{\mathbf{5 6}}$

These limits on tribal powers are relevant to an examination of the dynamics of Navajo taxing power over non-Indians in two very different ways. First, they dictate how the tribe must structure and administer the taxes

51. See note 44 supra.

52. 25 U.S.C. $\$ 637$ (1970).

53. Id. $\S \S 1301-41$.

54. Although early commentators on the Act doubted its applicability to non-Indians, judicial decisions have found it applicable. Compare Note, The Indian Bill of Rights and the Constitutional Status of Tribal Goternments, 82 HARv. L. Rev. 1343, 1364 (1969), with Dodge v. Nakai, 298 F. Supp. 17, 26 (D. Ariz. 1968) and Oliphant v. Schlie, Civil No. 51 1-73C2 (W.D. Wash., filed Apr. $5,1974)$.

55. This requirement was influenced by the fact that the earlier court decisions had suggested that Indian tribes were not subject to the Bill of Rights at all. The legislative history of the Act is described from competing points of view in Ziontz, In Defense of Tribal Sovereignty: An Analysis of Judicial Error in Construction of the Indian Civil Rights Act, 20 S.D.L. REv. 1 (1975) and de Raismes, The Indian Civil Rights Act of 1968 and the Pursuit of Responsible Tribal Self-Government, 20 S.D.L. REv. 59 (1975). See cases cited at note 19 supra.

56. Comment, The Indian Bill of Rights and the Constitutional Status of Tribal Governments, 82 HARV. L. REV, 1343 (1969). 
it decides to impose. They may, for example, prevent the Navajo Tribe from taxing only non-Indians or non-Navajos. ${ }^{57}$ Second, and more seriously, these limits open the possibility that tribal sovereignty will be subject to greater restraints in areas other than taxation should the tribe attempt to impose a tax on non-Indians, even if that tax is itself acceptable under the Act.

The major structural restriction on Navajo taxing power is the equal protection clause inserted in the Indian Civil Rights Act. Supreme Court interpretations of the equal protection provisions of the fifth and fourteenth amendments specify that ordinarily a law which treats groups of people differently must be rationally related to the achievement of some legitimate statutory purpose. ${ }^{58}$ However, where the law distinguishes between people with respect to their ability to exercise some constitutional right, ${ }^{59}$ or classifies people on the basis of an individual characteristic, such as race, that is beyond individual control and has historically been the basis for invidious treatment, ${ }^{60}$ the law must be necessary to achieve a compelling state interest. Very few laws have survived this latter requirement. ${ }^{61}$

Under these standards, a law taxing non-Indians or non-Navajos might survive, even though it smacks of discrimination against a racial or alien group. The Supreme Court has indicated that it will rarely second-guess legislative determinations about who should bear tax burdens, no matter which group receives the heavier burden. ${ }^{62}$ Moreover, distinctions involving Indians have not always been subjected to the rigorous scrutiny imposed on other racial distinctions. In the Supreme Court's 1974 decision in Morton $\%$ Mancari ${ }^{63}$ a federal statute giving preference to members of federally recognized Indian tribes in BIA hiring and promotions was upheld because the Court found that the classification was not racial but "political." The Court emphasized that people who are racially Indian but not members of federally recognized tribes

57. The Navajos currently grant preferences to tribal members in determining rentals for lease of tribal lands. Navajo Advisory Committee, Resolution No. ACJ-48-56, 1956, described in K. Gilbreath, Red Capitalism 39 (1973). Concern about the likely imposition of taxes on Navajos along with non-Navajos is partly responsible for lack of speed in implementing the Navajo Tax Commission. See text accompanying note 42 supra.

58. This principle is articulated in Reed v. Reed, 404 U.S. 71 (1971).

59. E.g., Dunn v. Blumstein, 405 U.S. 330 (1972).

60. E.g., Loving v. Virginia, 388 U.S. I (1967) (race); Graham v. Richardson, 403 U.S. 365 (1971) (alienage).

61. One notable exception is the law that produced the internment of Japanese-Americans in detention camps during World War II. Korematsu v. United States, 323 U.S. 214 (1944).

62. Thus in Kahn v. Shevin, 416 U.S. 351 (1974), Mr. Justice Douglas joined the Court in upholding the distribution of tax burdens on the basis of sex, even though he joined the plurality opinion in an earlier case viewing sex discrimination with the same suspicion as race discrimination. Frontiero v. Richardson, 411 U.S. 677 (1973) (opinion of Mr. Justice Brennan). Since allocation of tax burdens is perceived to be within the peculiar competence of local governing bodies, the Supreme Court is inclined to find a discriminatory tax law adequate to withstand any level of scrutiny.

63. 417 U.S. 535 (1974). 
would not qualify. Thus, the requirement of a "compelling state interest," applicable to racially discriminatory laws, will not necessarily apply whenever a distinction is drawn between Indians and non-Indians.

A tax imposed solely on non-Navajos would have a strong chance of surviving the less stringent rational relation test. Indeed, the demonstration of a reasonable relationship between such discrimination and a legitimate statutory purpose often has been found, as in Morton, where the goal of furthering Indian self-government sufficed. Federal (as opposed to tribal) discrimination in favor of Indians will almost always satisfy this requirement because of the federal government's trust and guardianship responsibilities with respect to Indians and the special constitutional provisions giving Congress authority over Indian affairs. A tax imposed by the Navajo tribe only on non-Navajos cannot be justified as easily. A justification based simply on the desire to favor one "political group" (Navajos) over others (non-Navajos) would be circular as well as suspect, given that the group imposing the tax was the exempt group. A rationale based on the fact that tribal members own the tribal resources might be plausible, however, since the tax would be on outsiders for the privilege of operating on the tribal territory. A more convincing argument would rest on the need to overcome the hardships and disadvantages long suffered by the Indians. This kind of justification sufficed to support a sex discriminatory $\operatorname{tax},{ }^{64}$ although it has never been applied by the Supreme Court to racial discrimination as such. ${ }^{65}$

Even if a tax on non-Navajos would not be acceptable on constitutional equal protection grounds, it is conceivable that the equal protection clause of the Indian Civil Rights Act imposes different requirements. A substantial body of legal literature ${ }^{66}$ argues that constitutional doctrine should be modified in interpreting identical provisions in the Indian Civil Rights Act, to take into account the distinctive culture and institutions of reservation tribes. Thus, for example, while tribes frequently make distinctions on the basis of blood quantum in distributing benefits among tribal members, ${ }^{67}$ distinctions which might well fall under the fifth and fourteenth amendments as racial classifications, ${ }^{68}$ these same distinctions might be upheld under the Indian Civil Rights Act as necessary to preserve tribal integrity, to maintain long-

64. Kahn v. Shevin, 416 U.S. 351 (1974).

65. The issue was avoided in DeFunis v. Odegaard, 82 Wash. 2d 11, 507 P.2d 1169 (1973), vacated as moot, 416 U.S. 312 (1974).

66. See articles cited in de Raismes, supra note 55 , at 59 n.2.

67. See,e.g., the Crow Creek Tribe's requirement that certain Tribal Council candidates be at least one-half blood, upheld in Daly v. United States, 483 F.2d 700, 705 (8th Cir. 1973).

68. There are some early Supreme Court decisions upholding federal distinctions among enrolled tribal members on the basis of blood quantum. E.g., United States v. Waller, 243 U.S. 452 (1917). None, however, squarely faced the equal protection issue. For a discussion of these cases see Vieira, Racial Imbalance, Black Separatism, and Permissible Classification by Race, 67 MICH. L. REV. $1553,1577-81$ (1969). 
standing tribal traditions, or to recognize tribal ownership. ${ }^{69}$ Some commentators would allow this deference only in situations where the tribal action reflects long-standing tradition essential to tribal culture, ${ }^{70}$ forgetting that although many modern tribal institutions have structures similar to those in white society they operate in uniquely Indian ways.

Under either standard of review, however, a tax only on non-Navajos would be little easier to justify under the Indian Civil Rights Act than under the fifth or fourteenth amendment. Separate treatment of outsiders for purposes of matters such as voting, jury service, issuance of grazing permits, and perhaps even freedom of speech, may be justifiable to maintain tribal identity and distinctiveness. The problem is that special taxation of outsiders has no connection with these values, except perhaps as a means of regulating entry by outsiders, or protecting the income and property of Indians whose traditional pursuits do not leave them with sufficient funds to pay taxes. Yet these possible connections are not viable if the tribe is simultaneously pursuing a policy of encouraging non-Indian enterprises on the reservation, ${ }^{71}$ or if the tax exemption for Navajos applies to non-Indian style entrepreneurs as well as sheep herders.

Assuming the Navajos are willing to tax their own people and outsiders alike (relying, for example, on steep graduation beyond a certain low income, or taxes on major industry only), the Indian Civil Rights Act may introduce a very different kind of restraint on the tribe. On the one hand, the potential in the Act for imposition of dominant values on tribal actions may enhance the likelihood that taxing power and other jurisdiction over non-Navajos will be upheld in the courts. ${ }^{72}$ On the other hand, the quid pro quo for this expanded jurisdiction over non-Indians might well be an increasing inclination on the part of the courts to force Indian governments into the mold of state

69. Other distinctions between "constitutional" requirements on and off reservations might be justified by the need for informality on reservations where bureaucratic institutions have not developed and government operates as an extended family. Ziontz, supra note 55, at 47-78. Imagine, for example, the impact on reservations of a holding that criminal cases with potential jail sentences must be heard by attorney judges. Such a requirement exists as a matter of due process in California. Gordon v. Justice Court for Yuba Judicial Dist., 12 Cal. 3d 323, 525 P.2d 72, 115 Cal. Rptr. 632 (1974).

70. de Raismes, supra note 55, at 82-85.

71. Navajo Nation, supra note 2, at 73-80.

72. Ziontz, supra note 55, at 56-57 and de Raismes, supra note 55. at 81-82, agree on this point. The Supreme Court's approving reference to the Indian Civil Rights Act in United States v. Mazurie, 419 U.S. at 558 n.12, which upheld tribal jurisdiction over non-Indians, reinforces this opinion. Although claims have been made that application of tribal rules to non-Indians violates due process because resident non-Indians cannot participate in formulating the rules, these claims have generally not led to invalidation of the rules themselves. See Memo, Jurisdiction of Indian Tribes to Prohibit Aerial Crop Spraying Within the Confines of a Reservation, 78 Interior Dec. 229 (1971), advising that Fort Hall Business Council Resolution No. 56-70, prohibiting all aerial spraying, does not violate due process served under 25 U.S.C. $\$ 1302(8)(1970)$ as to non-Indian lessees who had no opportunity to present their view on the measure prior to its enactment. A similar claim was rejected in United States v. Mazurie, 419 U.S. 544,558 n. 12 (1975). 
and local entities by interpreting the Indian Civil Rights Act provisions to mean the same thing as their Bill of Rights counterparts. For example, tribal rules limiting voting in tribal elections to enrolled members of the tribe might be invalidated on a theory analogous to the one used to strike down long residency requirements for voting in state elections, ${ }^{73}$ given the fact that there is no way to become part of the tribal body politic except by birth. ${ }^{74}$ Or tribal rules limiting service on juries or in tribal offices to Indians might be struck down on a theory analogous to those used in recent cases challenging exclusion of aliens from juries or civil service employment. ${ }^{75}$

This result should not be surprising if it is true that tribal power will be viewed expansively by the courts only so long as it is exercised within the bounds intended by the federal architects of tribal governments. As soon as tribal government appears to acquire the independence and permanence that significant exercise of taxing power brings, as soon as its institutions develop and Anglicize to the point where effective exercise of such jurisdiction is possible, and as soon as the tribe clearly indicates that its sovereign concern is everything that affects its territory (not simply its people), the courts may balk at deference to tribal definitions of expedient legislation that differ from dominant societal values, and courts may require participation by non-Indians in the legislative (e.g., taxing) process.

The Indian Civil Rights Act may have been enacted in contemplation of expanded tribal jurisdiction over non-Indians. Simultaneously Congress was encouraging long-term leasing of reservation lands to non-Indians, ${ }^{76}$ yet making it impossible for states to acquire jurisdiction over reservation Indians without consent of the affected Indians. ${ }^{77}$ The Civil Rights Act was the only remaining protection against imposition of alien cultural or political values on non-Indians. Thus tribal sovereignty may receive a freer rein the longer tribes choose to retain their self-contained, distinctive way of life. The Supreme Court's very different responses to non-normative policies of the expansionist Mormons on the one hand, ${ }^{78}$ and the isolated Amish on the other, ${ }^{79}$ illustrate

\footnotetext{
73. See, e.g., Dunn v. Blumstein, 405 U.S. 330 (1972).

74. 1 N.T.C. $\$ 102(1969)$.

75. See Sugarman v. Dougall, 413 U.S. 634 (1973) (state civil service); Mow Sun Wong v. Hampton, 500 F.2d 1031 (9th Cir. 1974) (federal civil service); Travers, The Constitutional Status of State and Federal Governmental Discrimination Against Resident Aliens, 16 HARV. INT'L L.J. 113 (1975). Even a Navajo might demand non-Indians on his jury under current definitions of the right to a representative jury. Peters v. Kiff, 407 U.S. 493 (1972).

76. 25 U.S.C. $\$ 415$ (a) (1970). Ninety-nine-year leases of Navajo land were first authorized in 1960. Pub. L. No. 86-505, 74 Stat. 199 (1960).

77. 25 U.S.C. $\$ \$ 1321-26$ (1970).

78. See Reynolds v. United States, 98 U.S. 145 (1878), upholding anti-polygamy laws in the face of challenge under the Free Exercise Clause; M. SHEPARDSON, supra note 1, at 113, where she notes " $[$ ] $]$ he futile efforts of the Mormons to establish an independent State of Deseret. . .."

79. See Wisconsin v. Yoder, 406 U.S. 205 (1972), striking down state compulsory school law's as applied to the Amish, whose religion. forbade formal education.
} 
this point. It is unlikely that the Navajos will be permitted to retain their sovereign distinctiveness while selecting out portions of the reservation for lucrative development by non-Indians. Since the cases suggest that tribal powers over non-Indians are not about to be denied altogether, ${ }^{80}$ the important question is how far the courts will go in fitting tribal governments to nonIndian models. The Indian Civil Rights Act is a powerful tool for accomplishing that purpose; and fears related to possible invocation of the Act may induce the tribe to negotiate with industry and competing sovereigns over revenues rather than assume the risks attendant with bold exercise of power.

\section{Secretarial Power to Approve or Disapprove Leases}

As trustee for tribally held and allotted Indian lands, the Secretary of the Interior or his delegate must approve every lease of that property. ${ }^{81}$ When the lease is for a very long term, Congress has required that prior to approval the Secretary shall first satisfy himself that adequate consideration has been given to "the availability of police and fire protection and other services [and] the availability of judicial forums for all criminal and civil causes of action arising on leased lands ...." 82

These secretarial powers can affect the exercise of Navajo taxing powers in several ways. Indirectly, the Secretary could refuse to approve leases generally or hinder the process of lease approval if he disfavored some tribal tax. More directly, the Secretary could refuse to approve a particular lease unless it contained a provision in which the tribe surrendered its power to tax. Several major industrial leases entered into by the tribe over the last fifteen years, including the lease for the Four Corners Power Plant and the Navajo Generating Station, contain just such waivers, although not necessarily at secretarial insistence. ${ }^{83}$ For example, the Four Corners lease prohibits taxation of property located on leased lands, leasehold rights granted in the lease, ownership, construction, and operation of facilities, generation or transmission of power, sale or disposal of power, company income, or sale or delivery of fuel to the company until 2005, when the tribe is then permitted to levy only a property tax, and at a rate one-half that of New Mexico or Arizona. Here is recognition of the tribe as property-owner, entitled to rents and royalties, but not as sovereign, entitled to taxes. ${ }^{84}$

Whether such lease provisions are enforceable against the tribe is unclear.

80. See text accompanying notes 26-32 supra.

81. 25 U.S.C. $\$ 415$ (1970). For a thorough description of the leasing process see Chambers \& Price, Regulating Sovereignty: Secretarial Discretion and the Leasing of Indian Lands, 26 STAN. L. REv. 1061 (1974).

82. 25 U.S.C. $\$ 415$ (a) (1970).

83. See G. Boyle, supra note 40 , at $7-8$.

84. This view of the tribe may be fostered by its counsel, who have always been private law firms rather than an "in-house" staff of government lawyers. 
If a hypothetical state that had agreed to forego assessing certain taxes later imposed those very taxes, the taxpayer would have a constitutional defense or claim based on the section of the Federal Constitution prohibiting any state from impairing the obligations of contracts. ${ }^{85}$ The Supreme Court has held, over powerful dissent, that a sovereign state is capable of contracting away its taxing powers. ${ }^{86}$ By contrast, a sovereign is incapable of contracting away its police power or its power of eminent domain. ${ }^{87}$ In deference to the sovereign, however, courts have gone out of their way to construe narrowly any exercise of the power to contract away taxing authority, to construe broadly any state constitutional restriction on contracting away taxing authority, and to characterize tax exemptions as legislative measures rather than contracts. ${ }^{88}$

This body of law is not easily related to the situation of the Navajo Tribe. The constitutional prohibition on impairment of the obligations of contracts has not been applied to Indian tribes under the Indian Civil Rights Act. It is uncertain, however, whether that means that a tribal tax imposed subsequent to an agreement not to tax would be treated simply as a potential deprivation of property without due process or would be subjected to more searching constitutional examination. A recent decision by the Navajo Court of Appeals $^{89}$ makes it clear that Navajo sovereign immunity ${ }^{90}$ will not save the tribe from suit if such claims are made under the Civil Rights Act. Should they be brought, the tribe might nevertheless invoke other precedents construing narrowly any arguable exercise of the power to contract away taxing authority. Following these precedents, the courts might decline to find any authorization for the Tribal Council to enter into such agreements, and invalidate the waivers. The tribe may be wary of suggesting such an approach, however, because it calls into question many principles the tribe would not want threatened-such as the Tribal Council's personification of all sovereignty possessed by the Navajo people, notwithstanding the lack of any constitution. Nevertheless, the tribe might argue that while the Council may have broad regulatory authority in the absence of a constitution, it wants the authority in the absence of a constitution to cede further sovereign powers in a contract. In one way or another, then, the tribe may be able to elude its agreement not to tax existing major industry on the reservation.

85. U.S. Const, art I, $\S 10$

86. Dartmouth College v. Woodward, 17 U.S. (4 Wheat.) 518 (1819); New Jersey v. Wilson,

11 U.S. (7 Cranch) 164 (1812).

87. Annot., 173 A.L.R. 15, 31 (1948).

88. Id. Thus, it might be possible to argue that the Tribal Council does not have sufficient authorization from the secretary to contract away tribal taxing power.

89. Halderman Dennison v. Tucson Gas \& Electric Co., Civil No. 12-74 (Navajo Ct. App., filed Dec. 23, 1974).

90. See, e.g., Thebo v. Choctaw Tribe, 66 F. 372 (8th Cir. 1895); cases cited in Ziontz, supra note 55, at $32 \mathrm{n} .124$ (immunity in federal court). This immunity can be lifted by Congress. Hamilton v. Nakai, 453 F.2d 152 (9th Cir. 1971). 
Even if the validity and enforceability of agreements not to tax are doubtful, secretarial insistence on including such provisions in leases might fail to comport with the Secretary's trust responsibility. ${ }^{91}$ In the case of long-term leases, however, the Secretary might justify such action on the basis of Congress's direction that he insure there has been adequate consideration of the availability of public services and judicial forums prior to approving such leases. Restrictions on tribal taxing power might be deemed appropriate to avoid possible tribal preemption of state taxing power under circumstances where the state is being relied on to provide the services and forums. The surrender of tribal taxing power would have to be carefully tied to this rationale, however, if the Secretary ever attempted to invoke it. For example, the tribe would have to be permitted to tax if it ever became willing and able to provide necessary services and court facilities.

In both indirect and direct ways, then, the Secretary may be able to restrain tribal taxing power through exercise of control over leasing tribal lands. As in the case of other federal controls, the existence of this potential for secretarial control may make the courts more comfortable about the prospect of recognizing tribal jurisdiction over non-Indians. But the price of this acceptability is the possibility of a secretarial veto whenever tribal sovereignty is exercised in ways that threaten non-Indian interests.

\section{Inhibitions Emanating from State Taxing Power}

As state and tribal governments compete for tax revenues arising from reservation activities by non-Indians, judicial doctrines and legislation that have protected tribes from state incursion may weaken. Not only do state officials fear that tribes may obtain advantages the states wish for themselves, or that tribal decisions will affect people who do not participate in their formulation, but they are also concerned that the states will be burdened by the demands for protection and education of non-Indians on the reservation without being allowed the necessary compensating revenues. ${ }^{92}$ State power to tax non-Indians on the reservations may preclude tribal taxation because of an explicit congressional grant of exclusive state power, because state taxation preempts tribal taxation even in the absence of congressional action, or because, as a practical matter, tribes are placed in an unfavorable bargaining

91. See Chambers \& Price, supra note 81; Chambers, Judicial Enforcement of the Federal Trust Responsibility to Indians, 27 STAN. L. REv. 1213, 1232-34 (1975). The secretary might take the position that a waiver of taxing power would increase the return measured in terms of rentals and royalties. But see Price \& Weatherford, Indian Water Rights in Theory and Practice: Navajo Experience in the Colorado River Basin, 40 Law \& Contemp. Prob. no. 1, at 97 (1976).

92. This concern with state responsibility for services in the absence of state entitlement to revenues already exists with respect to Indians, as courts have held Indians entitled to participate in state governmental benefits despite their immunities from state taxes. See Goldberg, Public Law 280: The Limits of State Jurisdiction Over Reservation Indians, 22 U.C.L.A.L. REv. 533 (1975). 
position when they try to impose taxes on non-Indian lessees in addition to those already levied by the state.

\section{Congressional Authorization for Exclusive State Taxing Power}

As part of its plenary control over Indian affairs, ${ }^{93}$ Congress has the power to confer exclusive jurisdiction on the states to tax Indians as well as non-Indians on reservations. Congress has never acted, however, to confer such jurisdiction on the states as a general matter. ${ }^{94}$ The closest Congress has come to conferring broad jurisdiction on the states is the enactment in 1953 of Public Law 280,95 which required six states ${ }^{96}$ and authorized the remainder to assert jurisdiction over reservation Indians. The Act was amended in 1968 to provide that no jurisdiction could be asserted by states merely authorized to assume it unless the affected Indians first consented in a referendum. ${ }^{97}$ In addition, the 1968 amendments permitted states that had been compelled to assume jurisdiction under Public Law 280 to return (retrocede) such power to the federal government. ${ }^{98}$

The statute preserved the tax-exempt trust status of Indians lands, ${ }^{99}$ although one circuit court of appeals has read the exemptions as permitting taxation of non-Indian leasehold interests in trust property. ${ }^{100}$ In addition, the Supreme Court held recently that the statute does not authorize any kind of state taxation of reservation Indians. ${ }^{101}$ Because Public Law 280 is addressed to state jurisdiction over Indians, this holding does not mean that states possessing jurisdiction under Public Law 280 may not tax non-Indians if they could have done so had the statute never been enacted. However, the decision does make it clear that Public Law 280 was not a broad or exclusive

\footnotetext{
93. Id. at 535, 563-67.
}

94. While one might construe Congress's directive to the Secretary to consider jurisdictional problems before approving long-term leases as a delegation of this authority, the Secretary has never promulgated comprehensive regulations. The only relevant regulations concern application of state zoning laws to leased lands. 25 C.F.R. $\$ 1.4$ (1974). They were adopted prior to the legislation incorporating this directive. 25 U.S.C. $\$ 415(\mathrm{a})$ (1970). For a suggestion that such regulations be promulgated see Note, Need for a Federal Policy in Indian Economic Development, 2 N.M.L. REv. 71, 79-80 (1972).

95. Act of Aug. 15, 1953, ch. 505, 67 Stat. 588-90 (now codified, as amended, in scattered sections of 18 and 28 U.S.C.). For an analysis of the Act, see Goldberg, supra note 92.

96. Alaska, California. Minnesota, Nebraska, Oregon, and Wisconsin, with the exception of certain named reservations, fell into this category.

97. 25 U.S.C. $\$ \S 1321-26(1970)$.

98. Id. $\$ 1323$. For a discussion of retrocession see Goldberg, supra note 92, at 558-92. Public Law 280 jurisdiction has been assumed in whole or in part by Florida, Idaho, Iowa, Montana, Nevada, North Dakota, South Dakota, and Washington. Id. at 567-69 and accompanying notes. 99. The Act also preserved treaty and statutory rights with respect to hunting, fishing, and land use even after states had acquired this jurisdiction. 28 U.S.C. $\S 1360$ (b) (1970); 18 U.S.C. $\S$ 1162 (b) (1970).

100. Agua Caliente Band of Mission Indians v. County of Riverside, 442 F.2d 1184 (9th Cir. 1971), cert. denied, 405 U.S. 933 (1972).

101. Bryan v. Itasca County, 96 S. Ct. 2102 (1976). 
grant of state taxing power over Indians and non-Indians on reservations.

Federal law does appear to authorize state taxation of mineral extraction on Indian trust lands. ${ }^{102}$ However, this limited provision does not render state taxing power exclusive.

\section{State Preemption of Tribal Taxing Power Over Non-Indians} Absent Congressional Authorization

More interesting is the scope of state taxing power when the state possesses no Public Law 280 jurisdiction. ${ }^{103}$ This is the case on the Navajo reservation: Arizona, New Mexico, and Utah-the states containing the Navajo Reservation-did not assume jurisdiction prior to 1968 (although Utah did so afterwards), ${ }^{104}$ and the Navajos have never voted in favor of such jurisdiction. ${ }^{105}$

In the absence of congressional allocation of exclusive jurisdiction to the states, the states nevertheless have argued that their exercise of regulatory power over non-Indians on reservations can preempt any tribal powers. One potential judicial response to increased assertiveness of tribes like the Navajo may be to strengthen the doctrinal underpinning of the states' argument. The source of this argument involves Supreme Court cases denying federal (and by implication, tribal) jurisdiction over crimes committed by one nonIndian against another on the reservation in favor of exclusive state jurisdiction. ${ }^{106}$

It is unlikely that the law will evolve in this direction, however. The logic of the original cases upholding exclusive state jurisdiction is under increasing attack, as commentators point out that activities by non-Indians may legitimately concern the tribe. ${ }^{107}$ These observations are correct even if the tribal government is still functioning merely as a transitional agent of assimilation and indirect rule. Laws prohibiting interference with activities of tribal police, ${ }^{108}$ traditional Indian ceremonies or burial grounds, ${ }^{109}$ or tribal deci-

102. 25 U.S.C. $\$ 398$ (1970); see British-American Oil Producing Co. v. Board of Equalization, 299 U.S. 159 (1936). For an interpretation of this statute that would deny state taxing power over lessees engaged in mineral production while permitting state taxation of the royalties Indian tribes receive from such production see Comment, The Case for Exclusive Tribal Power to Tax Mineral Lessees of Indian Lands, 124 U. PA. L. REv. 491, 515-20 (1975).

103. The number of states lacking Public Law 280 jurisdiction may well increase if legislation is passed permitting tribes to effect retrocessions. See S. 1328, 94th Cong., Ist Sess. (1975).

104. Arizona has improperly asserted Public Law 280 jurisdiction over air and water pollution, but the assumption has never been challenged. Ariz. Rev. Stat. Ans. $\$ \S 36-1801,1865$ (1974). For a critique of Arizona's effort see Goldberg, supra note 92, at 554-57. Utah's assumption is found in Utah Code AnN. $\$ 63-36-9$-21 (Spec. Supp. 1975).

105. Under the Act, the Navajos in Arizona, New Mexico, or Utah could accept the Act for their territory independently of the rest.

106. E.g., Draper v. United States, 164 U.S. 240 (1896).

107. See note 31 supra.

108. See Oliphant v. Schlie, Civil No. 511 -73C2 (W.D. Wash., filed Apr. 5, 1974).

109. See 1 National American Indian Court Judges Ass'n, The Impact of Public Law 280 
sions to limit the sale of liquor on the reservation ${ }^{110}$ would fall within such appropriate federal and tribal regulation. Accordingly, there is no reason to assume that state efforts to control non-Indians in these respects ought to be exclusive, especially so long as one sovereign is not requiring parties to do what the other prohibits. ${ }^{11}$ Indeed, as will be discussed below, it is not even reasonable that state jurisdiction in such areas ought to prevail when it conflicts or overlaps with exercise of tribal sovereignty. Thus a general rule rendering state jurisdiction preemptive with respect to non-Indians will be more and more difficult to justify.

The Supreme Court's decision in Mazurie ${ }^{12}$ confirms this impression. There the State of Wyoming already had laws providing for licensing of the sale and distribution of liquor. Non-Indians who had complied with those laws were prosecuted under federal law for selling liquor on the reservation in violation of different tribal regulations respecting the same subject. Without referring to the cases supporting exclusive state jurisdiction over crimes by and against non-Indians, the Court announced that tribal jurisdiction over non-Indians persisted despite state legislation on the same subject, at least in the case of "matters that affect the internal and social relations of tribal life."113 Thus, if tribal jurisdiction to tax non-Indians exists in the absence of state efforts to tax, that jurisdiction can probably survive the exercise of any concurrent state taxing power.

Whether such "double taxation"114 would discourage location of development on Indian reservations is a separate problem. Certain activities, such as mineral extraction, are not mobile, although resources on Indian reservations compete with resources located elsewhere. However, the most lucrative tax sources-industrial works and employees-could be located either on or off reservations.

Upon the Administration of Justice on Indian Reservations, in JUSTICE AND THE AMERICAN INDIAN (1973).

110. See United States v. Mazurie, 419 U.S. 544 (1975).

111. Such situations rarely occur. The likelihood of their occurring is discussed in the debate over dividing the Ninth Circuit Court of Appeals into two circuits, each containing part of California. Problems would ensue if the two circuits in California imposed conflicting requirements. Comm'n on Revision of the Federal Court Appellate System, The Geographical Boundaries of the Several Judicial Circuits: Recommendations for Change, 62 F.R.D. 223, 238-39 (1974).

112. United States v. Mazurie, 419 U.S. 544.

113. Id. at 557.

114. This would not be the constitutionally forbidden form of double taxation which involves multiple actions by a single sovereign. Generally speaking, it is permissible for more than one sovereign to tax property or activities, if the property or activities fall within more than one jurisdiction. Apportionment is required, however, if, for example, property is used in two different states. See, e.g., In re McLean Trucking Co., 281 N.C. 375, 189 S.E.2d 194 (1972). None of this precedent concerns a hypothetical situation in which territory falls within two states' boundaries, the only situation that would approximate an Indian reservation. 


\section{Can Tribal Taxation Preempt State Taxation?}

Tribal fears of multiple taxation would vanish if a tribal tax could render any state tax on the same activity or property illegal. Existing Supreme Court doctrine provides support for such an argument in the absence of congressionally authorized state taxation. ${ }^{15}$ The Court has held that states have no jurisdiction over reservation activities or property where that jurisdiction would interfere with "the right of reservation Indians to make their own laws and be ruled by them"116 or would "affect the internal and social relations of tribal life."117 State regulation of non-Indians has not generally been regarded as an interference with tribal government or society. ${ }^{118}$ Thus in Noriell $\%$. Sangre de Cristo Devielopment Company, ${ }^{119}$ the District Court of New Mexico upheld the state's power to impose a leasehold and gross receipts tax on a nonIndian company leasing Indian lands for the creation of a recreation home subdivision adjacent to a large city. While recognizing that the taxes would adversely affect the commercial value of the Indian land, the court held that such taxes did not "do violence to the governmental powers of the pueblo."120 The Indians might have argued that higher rentals were part of an overall development plan that would be undermined by state taxation. ${ }^{121}$ But since the tribe had no plans to provide any services to the development and the burden for their provision would have fallen entirely on the state and local governments, it is understandable that the court failed to perceive any threat to the Pueblo's sovereignty from the imposition of state taxation.

A very different application of the doctrine enunciated in Norvell may, therefore, be expected when the tribe has an ongoing interest in non-Indian activity or property on the reservation: for example, when the tribe is already taxing the same matters, has a major financial interest in the venture, ${ }^{122}$ is

115. For an example of such a tax, see note 102 supra and accompanying text.

116. Williams v. Lee, 358 U.S. 217,220 (1959).

117. United States v. Mazurie, 419 U.S. at 557.

118. Cases involving state taxation of non-Indians include Confederated Salish \& Kootenai Tribes v. Moe, 392 F. Supp. 1297 (D. Mont. 1975), aff'd, 96 S. Ct. 1634, 1645 (1976); Oklahoma Tax Comm'n v. Texas Co., 336 U.S. 342 (1949); Thomas v. Gay, 169 U.S. 264 (1898); Utah \& Northern Ry. v. Fisher, 116 U.S. 28 (1885); Kahn v. Arizona State Tax Comm'n, 16 Ariz. App. 17, 490 P.2d 846 (1971).

119. 372 F. Supp. 348 (D.N.M. 1974), reild on other grounds, 519 F.2d 370 (10th Cir. 1975).

120. 372 F. Supp. at 358 .

121. Such a showing might have brought the case closer to the cirumstances of White Mountain Apache Indian Tribe v. Shelley, 107 Ariz. 4, 480 P.2d 654 (1971), in which the Arizona Supreme Court extended tribal sovereign immunity from suit to a profit-making entity authorized under the tribal charter as a means of furthering the tribe's economic development plans. Absent that kind of showing, the Pueblo in Norvell appeared to be acting more as a landowner than as a sovereign whose powers were under attack.

122. The tribe might, for example, lease to a corporation incorporated under tribal law, with itself or some tribal enterprise as a minor but not insignificant shareholder. The tribal shares might be in exchange for a lower lease price or a contribution of minerals to the project under- 
providing services and governmental support, or the venture is integrally connected with tribal economic development. Of course, it is not easy to predict how much tribal involvement is enough to preclude state jurisdiction. It may be that the mere existence of a tribal tax will suffice, on the theory that an infringement of tribal sovereignty always exists where state and tribe attempt to derive revenue from the same source. But where the purpose of a state taxing scheme is seen as the regulation of various activities, the provision of a higher level of public services, or the redistribution of income, tribes will probably have to be doing more than simply collecting tax revenues in order to preempt state jurisdiction.

An example of a situation that would present a compelling case for tribal preemption of state taxing power is a proposed "new town" for the Navajo Reservation to house Navajo and other employees of contemplated coal gasification plants in the eastern reservation. The plans as presented in a consultant's report ${ }^{123}$ suggest joint participation by the Navajo Nation and gasification companies in creating a non-profit development corporation to lease the land for the town, prepare the physical and social plan, obtain longterm financing for construction, promote retail and service uses in the new town, and so on. When the property has been developed and transferred to individuals for residential, business, and industrial use, a local governmental body accountable to the Navajo Tribal Council would set policy and provide public services other than education. The ultimate goals would be enhancement of reservation life through creation of a uniquely Navajo urban environment and the increase in tribal capacity to benefit economically from extraction of its precious resources. ${ }^{124}$ Given the connection between revenue raising and tribal plans for management of non-Indians' activities on the reservation, a court might be inclined to prohibit state intervention in tribal fiscal plans as an infringement on tribal sovereignty. What makes the case particularly appealing is the tribal provision of most public services.

Doctrinally, the preemptive impact of tribal taxes would seem to depend on what the tribe does in addition to taxing. Practically, it may also depend on how long the tribe waits to institute a taxing scheme. Since state taxes on non-Indians are probably permissible in the absence of a tribal taxing scheme, it may be more difficult for courts to disrupt state expectations or to invali-

taken on leased land. A state tax on the corporation itself (as opposed to a tax on dividends paid the non-Indian shareholders) then would be a direct and impermissible burden on the tribe, even if a fraction of the corporate tax was assessed corresponding to the fraction of non-Indian shareholders. $C f$. Makah Indian Tribe v. Callam County, 73 Wash. 2d 677, 440 P.2d 442 (1968) (community property of Indian wife and non-Indian husband wholly exempt from state personal property tax).

123. Development Research Associates, Housing and Community Services for Coal Gasification Complexes Proposed on the Navajo Reservation (1974).

124. Id. at 11-2, 11-3. 
date a tax that has been permissible for years. ${ }^{125}$ Accordingly, the tribe ought to resolve doubts about its taxing power in favor of attempting to invoke it, since delay in doing so may destroy its preemptive force. At the same time, it must avoid premature assumptions that cannot be accompanied by sufficient additional tribal involvement.

Finally, the prospects for tribal taxation preempting state taxation should be evaluated in light of the dynamic of tribal sovereignty suggested in this article. It is quite possible that even under the propitious circumstances of the "new town" discussed above, tribal taxing power will not be found preemptive, because the courts are reluctant to acknowledge Indian tribes as such powerful and independent governing entities. The permanence and selfsustaining nature of such a "new town" government would not be consonant with the prevailing assumptions about tribal government.

As reservation peoples and development blend in with surrounding nonIndian communities, the Navajo Tribe will be pressured either to take on characteristics and responsibilities of non-Indian governments, or to surrender powers to the states-if not by state taxation, then by termination. ${ }^{126}$ While the former alternative may preserve tribal taxing power, it is uncertain that even the relatively wealthy and advanced Navajos are capable of assuming the responsibility; even if they are capable, they may do so at the expense of tribal exclusivity and cultural distinctiveness. To avoid such negative consequences, as well as costly litigation, it may be necessary for the tribe to seek a congressionally sanctioned compromise or to negotiate directly with the states for sharing of revenues and responsibilities. ${ }^{127}$

125. By analogy, because the Supreme Court has been unwilling to review lower court decisions ruling against challenges to state assumptions of jurisdiction under Public Law 280, courts have begun upholding state jurisdiction in order to avoid defeating expectations of those who have relied on it. Tonasket v. State, 84 Wash. 2d 164, 525 P.2d 744, 753 (1974).

Interestingly, for the case of the Navajos, Arizona and New Mexico are moving quickly to impose leasehold taxes as substitutes for a property tax. See Reno, supra note 2, at 362. New Mexico already imposes personal property, severance, and sales taxes on the Four Corners power plant complex, located on Indian land. These taxes have never been challenged in court. See Farmington (N.M.) Daily Times, supra note 2.

126. See Agua Caliente Band v. County of Riverside, 442 F.2d 1184 (1971) (upholding leasehold tax in a Public Law 280 state); see note 98 supra. T. TAYLoR, supra note 28, at 153 n.17 states that

[t]he non-Indian population might not support continued trust status for a wealthy lndian group over an extended period of time. However, various State governments are experimenting with a possessory interest tax which, if held legal by the courts, may erode the tax protection provided by trust and therefore take the pressure off eliminating trust status, as such, even for a wealthy Indian group.

127. Preliminary steps in the direction of negotiation are evident in AMERICAN INDIAN LAw Center, Taxation and Sovereignty (1975), written for the New Mexico Commission on Indian Affairs. 


\section{Conclusion}

Tribal taxing power over non-Indians seems to have a firm basis in current judicial doctrine, as does state taxing power. Furthermore, there are few direct federal restraints on the exercise of this tribal power, and little likelihood that state taxation will preempt it. Indeed, under certain circumstances the tribes may preempt the state with their taxes. The legal framework is dynamic, however, and may change as tribes such as the Navajo depart from their original weak governmental form. Federal restraints may be increased through the mechanism of the Indian Civil Rights Act, especially in the direction of homogenizing tribal governments with state and local counterparts. Freedom from state taxation may be available only if the tribes take on functions traditionally performed by the state.

Significantly, both of these developments propel a strong tribe like the Navajo in the direction of becoming a state itself, a subordinate entity within a state, or a commonwealth such as Puerto Rico. To the extent that the courts perceive these consequences with fear or concern, the judicial tendency may be to deny tribal taxing power over non-Indians altogether. The result will depend largely on what tribes such as the Navajo do wth respect to conceiving and implementing their power to tax. The ultimate lesson, however, is that jurisdictional doctrine cannot be understood apart from the historical, political, and institutional framework within which it is applied. Jurisdictional rules may be framed in terms of sovereignty, but they evolve as prevailing assumptions about the functions of power change and as the consequences of the exercise of that power change as well. 